\title{
Creating Socially Aware Engineers through International Service Learning
}

\section{Dr. Sandra Loree Dika, University of North Carolina, Charlotte}

Dr. Sandra Dika is an assistant professor of Research Methods in the Department of Educational Leadership at the University of North Carolina at Charlotte. Her research interests are focused on student engagement and success in college, particularly among underrepresented students in STEM fields. She collaborates frequently with engineering educators on research projects and evaluations of programs and curricula.

Dr. Brett Tempest, University of North Carolina, Charlotte

Dr. Miguel A. Pando, University of North Carolina, Charlotte

Dr. Miguel Pando is an associate professor in the Civil and Environmental Department of UNC Charlotte. 


\section{Creating Socially Aware Engineers through International Service Learning}

A great deal of research and policy attention in the last decade has emphasized the need to reform engineering education to produce engineering professionals that can respond to changing societal needs (e.g., ASCE, 2007; 2008; Duderstadt, 2008; NAE, 2005; Rugarcia et al., 2000). In engineering programs, student outcome " $h$ " of the Accreditation Board for Engineering and Technology's (ABET) accreditation criteria specifies that engineers must have a broad education necessary to understand the impact of engineering solutions in an environmental and societal context (ABET, 2012). The traditional engineering curriculum offers few opportunities to truly integrate societal and cultural contexts into the design of engineering solutions, let alone international contexts.

In conjunction with an Engineers without Borders (EWB) student chapter, the second and third authors of this paper led a study abroad program with a significant service learning component in a remote mountain village in Peru in Summer 2012. Student participants included 10 civil engineering students (9 undergraduate and 1 graduate) at a large urban research institution in the southeast United States. With the first author, they designed pre- and post-trip questionnaires, focus group interviews, and written reflection activities to assess students' perceptions, attitudes, and learning as a result of the experience. This paper addresses three research questions:

1) What is the profile of engineering students who choose to participate in a study abroad/ service learning experience, in terms of motivation for enrolling in study abroad, reasons for volunteering, and previous educational, organization and service activities? 
2) How do engineering student participants understand the role of engineering in society and the incorporation of community and societal needs in the design of engineering solutions, before and after the study abroad/service learning experience?

3) Are there differences in attitudes toward engineering and perceived learning opportunities (related to ABET a-k outcomes) before and after the study abroad/service learning experience?

Our data analysis approach includes descriptive statistics as well as thematic analysis of focus group responses. Due to the size of the sample and the duration of the experience (1 month), we did not anticipate statistically significant changes in attitudes and perceived learning opportunities (research question 3).

\section{Description of Study Abroad Experience}

The study abroad course was developed in conjunction with the institution's Engineers without Borders chapter. Students participating in the experience completed a total of four credit hours - three hours for an interdisciplinary course entitled Engineering for Development Workers, and one hour for a structural or geotechnical engineering laboratory course. Prior to the trip, participants attended a seminar series which included four half-day sessions led by subjectmatter experts from other academic departments, including Development Patterns in Latin America, The Ethics of Assistance, Technical Challenges in Development, and Social Capital and the Community. Further, students completed a portion of the laboratory hours during this pre-trip week.

The Peru-based study abroad experiences involved classroom and laboratory sessions at a host institution in Lima along with the site-based experience in the Cusco region. The engineering co-authors of the paper had visited the institution and the village site during the 
previous summer to meet with representatives and begin developing the experience. During two weeks of study, students attended sessions on the notion of appropriateness of technology; water, thermal, and rural housing systems; sanitation; technology transfer; sustainability and development; needs assessment strategies; along with test methods and measurements in the lab. Sessions were led by engineering and rural development faculty at the host institution. For the final eight days of the study abroad course, the students conducted field work at the village site in collaboration with leaders and workers in the village. The final project involved the design and construction of a bridge for pedestrian and livestock crossing - the most pressing concern as expressed by the community.

\section{Data Sources}

The data sources for this study include pre- and post-trip questionnaires and focus groups. All instrumentation was developed by the co-authors of the paper, with some adaptation of existing instruments on engineering attitudes, volunteering, and extracurricular activities. The pre-trip questionnaire included questions on reasons for enrolling in the study abroad, enriching educational activities, attitudes toward engineering, reasons for volunteering, and expectations regarding ABET a-k learning outcomes, as stated by the department. The post-trip questionnaire repeated the items on attitudes toward engineering and engineering learning outcomes, including the opportunity to comment on each of the learning outcomes. Students were also asked about their perceptions of the project's value to their learning and to the community, along with their future educational and career plans.

The pre-trip focus group included a discussion of questions related to expectations about how the experience would enrich their engineering education, the role of engineering in society, the role of service in engineering education, professional responsibility when dealing with other 
cultures, and any anticipated problems or issues. The post-trip focus group questions focused on student perceptions of how the experience enriched their education, how it changed their thoughts about career options for the future, perceptions of teamwork in relation to the changed project focus, the role of service in engineering, and recommendations for future iterations of the program. Written reflections following specific questions were also collected from the students, but these responses are not analyzed for this paper.

\section{Research Question 1: Profile of Student Participants}

The participating civil engineering students included 4 women and 6 men, most of whom were members of the Engineering without Borders chapter. Reasons for enrolling in the study abroad expressed by the participants included travelling abroad and experiencing other cultures; experience in international/development work; the particular location (Latin America); receiving course credit; hands-on learning experience; and helping others. Six of the students had previous experience with community service or volunteer work, three had foreign language coursework, and one had previous study abroad experience. Three of the students spoke fluent Spanish. All students had participated in engineering clubs and student organizations during the previous academic year, while eight had participated in other non-engineering organizations and activities. In responding to statements about importance of different reasons for doing volunteer and service work, items that received the highest number of extremely important rankings were "volunteering allows me to gain a new perspective on things" (70\%), "I feel compassion toward people in need" (70\%), and "I feel it is important to help others" (70\%). Half of the participants indicated that "volunteering allows me to explore different career options" was an extremely important reason for volunteering. 


\section{Research Question 2: Role of Engineering in Society and the Incorporation of Community and Societal Needs in the Design of Engineering Solutions}

Students emphasized the role of engineering, particularly civil engineering, in society to be related to improvement of living conditions and responsible implementation of technology. Further, their responses emphasized the need for cultural awareness and consideration in the design of solutions, particularly related to the project they were to embark on (pre-trip).

"When you say that you're improving people's lifestyle, that's kind of a subjective thing. Like who's to say that's actually improving it. It depends on each person individually."

"I wouldn't want to just go down there and set up a project for them and them not understanding what's going on, this has to be like an opportunity to teach, and work with them, not just "Oh we're here, we're gonna take care of it."

"It's to take the technology that we do have, implement it in this society but responsibly so it doesn't have a negative cultural effect"

Post-trip, students commented on the development of their own social awareness. One of

the male students expressed making the connection.

"A project like this, really brings together the math and the science with the social, emotional side and ties it together and it makes you really I think, for me anyway, I gained a lot from that connection and it's easier now to come back and sit through a class and then having that experience kind of continued to make that connection whereas prior to the trip I definitely wasn't I guess, if that makes any sense."

Students also talked about incorporation of community and social needs in discussing their project. The project focus changed and students were asked specifically to talk about how they worked through that with each other and with the village leaders and workers who were assigned to help them build the bridge. They indicated initially that they adapted relatively easily to the change.

"I don't think anybody it really mattered what we were doing as long as we were going to do development work on infrastructure to help the community which is why we were there..."

"You just need to know we're there for a reason and umm yeah we were there for two days doing, working on one project that we thought we would be completing and come to find out that you know you got the, not necessarily waste two days, but you utilized two days of your time to 
where you could be doing work to you know, trying to fit these people's needs and how we change, I mean changing the task was just something that you had to do but we all knew that we had to do it so we had to listen to them since you're not familiar with their culture or anything like that."

"We thought we were all doing the right thing and because of the culture aspect of it, it turned out that we weren't and so we all just kind of 'alright let's shift gears, and see, you know we don't wanna go home yet, let's see what else we can do..."

With further discussion, particularly about how to improve the experience for future iterations of the course, students talked about the need for better preparation and a multidisciplinary team to design and implement an appropriate solution for the social and cultural context.

"Yeah like the social aspect because that was a point that we really struggled, that was maybe our biggest error was the cultural and social aspect of the trip. So to incorporate a few more, especially Spanish speaking people, but not only that, people that know how to approach that kind of situation and how to handle those kinds of things, I think really would've helped us out...the engineers grabbed the tools and started running and that's kind of where we hit our problem or, so I think incorporating more of that aspect would be beneficial."

\section{Research Question 3: Attitudes toward Engineering and Engineering Outcomes}

Participants indicated their attitudes toward engineering prior to and after the study abroad trip. Table 1 displays the percent of students responding strongly agree and agree to each statement at each time point. As would be expected given the programmatic stage of the students (junior, senior, graduate), the participants have positive attitudes toward the engineering career and engineering's role in society and the world, however do not see engineering degree as a guarantee for a job. 
Table 1: Participant agreement with statements on attitudes toward engineering, pre- and posttrip

\begin{tabular}{|c|c|c|}
\hline & $\begin{array}{c}\text { PRE-TRIP } \\
(\mathrm{n}=10)\end{array}$ & $\begin{array}{l}\text { POST-TRIP } \\
(\mathrm{n}=9)\end{array}$ \\
\hline I expect that engineering will be a rewarding career. & $100 \%$ & $100 \%$ \\
\hline $\begin{array}{l}\text { Engineers contribute more to making the world a better place than people in most } \\
\text { other occupations. }\end{array}$ & $70 \%$ & $67 \%$ \\
\hline I am studying engineering because I enjoy figuring out how things work. & $100 \%$ & $100 \%$ \\
\hline The advantages of studying engineering outweigh the disadvantages. & $100 \%$ & $100 \%$ \\
\hline $\begin{array}{l}\text { Engineering is more concerned with improving the welfare of society than most other } \\
\text { professions. }\end{array}$ & $80 \%$ & $78 \%$ \\
\hline $\begin{array}{l}\text { Preparation in liberal studies (e.g., history, economics, sociology, psychology, fine } \\
\text { arts, languages) is important for an engineer. }\end{array}$ & $80 \%$ & $89 \%$ \\
\hline Engineers are innovative. & $100 \%$ & $100 \%$ \\
\hline Engineering involves finding precise answers to problems. & $90 \%$ & $89 \%$ \\
\hline I like the professionalism that goes with being an engineer. & $90 \%$ & $78 \%$ \\
\hline Engineering is an occupation that is respected by other people. & $100 \%$ & $100 \%$ \\
\hline The future benefits of studying engineering are worth the effort. & $100 \%$ & $100 \%$ \\
\hline Engineers have contributed greatly to fixing problems in the world. & $100 \%$ & $78 \%$ \\
\hline Engineers are creative. & $90 \%$ & $78 \%$ \\
\hline Technology plays an important role in solving society's problems. & $90 \%$ & $67 \%$ \\
\hline Engineering is an exact science. & $50 \%$ & $33 \%$ \\
\hline I can think of other majors that would be more rewarding. & $10 \%$ & $11 \%$ \\
\hline An engineering degree will guarantee me a job when I graduate. & $40 \%$ & $33 \%$ \\
\hline
\end{tabular}

While the opinions pre- and post-trip generally do not show any marked differences, there are some worth noting related to social awareness. Post trip, a slightly greater proportion of participants agreed with the importance of liberal studies for engineers ( $80 \%$ to $89 \%)$. For two statements, there was a lower proportion of agreement after the trip - engineers have contributed 
greatly to fixing problems in the world $(100 \%$ to $78 \%)$ and technology plays an important role in solving society's problems (90\% to 67\%). This slight change may reflect the students' experience at the service learning site where, in responses to other questionnaire items, they noted the need for multidisciplinary teams as well as the need to use basic materials available versus the most technologically advanced solution.

Students expressed high expectations for engineering learning outcomes prior to the trip. Students overwhelmingly agreed that they expected the experience to enhance these outcomes, as shown in Table 2, column 1. When evaluating their learning as a result of the experience (column 2), expectations were not quite met for some of the learning outcomes - ability to apply math, science, and engineering knowledge; ability to design and conduct experiments; ability to identify, formulate, and solve engineering problems; and recognition of the need for and ability to engage in lifelong learning. However, because one participant was not able to complete the post-trip questionnaire, these differences should not be over-emphasized. The more relevant information comes from student comments (column 3) that illustrate how students' social awareness was enhanced from the experience at the host institution and in the village - listening to the community members and addressing their needs, understanding social and cultural aspects of the community, and ethical responsibility and long-term impacts were all important learning mentioned by students. 
Table 2: Participant agreement with statements about expected and achieved learning outcomes, with example post-trip comments

\begin{tabular}{|c|c|c|c|}
\hline & $\begin{array}{l}\text { PRE-TRIP } \\
\text { Expected } \\
(\mathrm{n}=10)\end{array}$ & $\begin{array}{l}\text { POST- } \\
\text { TRIP } \\
\text { Achieved } \\
(\mathrm{n}=9)\end{array}$ & Illustrative POST-TRIP comments \\
\hline $\begin{array}{l}\text { Ability to apply knowledge of mathematics, } \\
\text { science, and engineering to solve engineering } \\
\text { problems }\end{array}$ & $100 \%$ & $89 \%$ & $\begin{array}{l}\text { "Being hands on with the work; such } \\
\text { as designing and building the bridge, } \\
\text { put everything into perspective." }\end{array}$ \\
\hline $\begin{array}{l}\text { Ability to design and conduct experiments, as } \\
\text { well as analyze and interpret data }\end{array}$ & $100 \%$ & $89 \%$ & $\begin{array}{l}\text { "Learning at a lab in a different } \\
\text { country was interesting and gave a } \\
\text { new perspective." }\end{array}$ \\
\hline $\begin{array}{l}\text { Ability to design a system, component or } \\
\text { process to meet desired needs }\end{array}$ & $100 \%$ & $89 \%$ & $\begin{array}{l}\text { "We were able to listen to the people } \\
\text { of the village to find out what work } \\
\text { they needed and fulfilled that need." }\end{array}$ \\
\hline Ability to function on multidisciplinary teams & $100 \%$ & $100 \%$ & $\begin{array}{l}\text { "We were split into groups in the } \\
\text { village and everybody handled their } \\
\text { part..." } \\
\text { "Had to work with social aspects of } \\
\text { the community itself." }\end{array}$ \\
\hline $\begin{array}{l}\text { Ability to identify, formulate, and solve } \\
\text { engineering problems }\end{array}$ & $100 \%$ & $78 \%$ & $\begin{array}{l}\text { "We had definitive problem that we } \\
\text { solved - the community needed a } \\
\text { new bridge." }\end{array}$ \\
\hline $\begin{array}{l}\text { Understanding of professional and ethical } \\
\text { responsibility }\end{array}$ & $100 \%$ & $100 \%$ & $\begin{array}{l}\text { "Huge emphasis on ethics and } \\
\text { responsibility! Great experience not } \\
\text { otherwise gained in school." } \\
\text { "Miscommunication with the } \\
\text { community members over water } \\
\text { distribution system issue." } \\
\text { "Ethical responsibility really played a } \\
\text { part during our first few days in the } \\
\text { village." }\end{array}$ \\
\hline Ability to communicate effectively & $100 \%$ & $100 \%$ & $\begin{array}{l}\text { "Not knowing Spanish, my ability to } \\
\text { use body language to communicate } \\
\text { was enhanced." } \\
\text { "Communication was critical under } \\
\text { time constraints." }\end{array}$ \\
\hline $\begin{array}{l}\text { Broad education necessary to understand the } \\
\text { impact of engineering solutions in a global and } \\
\text { societal context }\end{array}$ & $100 \%$ & $100 \%$ & $\begin{array}{l}\text { "Without the efforts of our class, this } \\
\text { village would still have an unsafe } \\
\text { bridge." } \\
\text { "Knowing long-term impacts of what } \\
\text { we did as well as previous NGO." } \\
\text { "Engineers are needed everywhere." }\end{array}$ \\
\hline $\begin{array}{l}\text { Recognition of the need for and ability to } \\
\text { engage in lifelong learning }\end{array}$ & $100 \%$ & $89 \%$ & No comments \\
\hline Knowledge of contemporary issues & $90 \%$ & $89 \%$ & $\begin{array}{l}\text { "Get to see them first hand." } \\
\text { "Understanding the cultural climate } \\
\text { of the area we were working in." }\end{array}$ \\
\hline $\begin{array}{l}\text { Ability to use techniques, skills, and modern } \\
\text { engineering tools necessary for engineering } \\
\text { practice }\end{array}$ & $100 \%$ & $100 \%$ & $\begin{array}{l}\text { "More hands on than traditional } \\
\text { labs/class." } \\
\text { "With our student knowledge, we } \\
\text { had to produce a functioning bridge } \\
\text { in roughly a week." }\end{array}$ \\
\hline
\end{tabular}




\section{Discussion and Future Directions}

This paper presented the results of a study of student experiences and perceptions, particularly related to social awareness, after participating in a service-based study abroad experience in Andean Peru. The analyses of the research questions revealed some encouraging findings.

Students who chose to participate in the experience were motivated by wanting to travel abroad and experience other cultures; gain experience in international/development work; receive course credit; gain hands-on learning experience; and help others. Helping others was also one of the primary reasons for volunteering expressed by the students, as well as having compassion for people in need. Students also indicated they volunteer to gain a new perspective.

The focus group discussions indicated that students had developed some social awareness and sense of engineering's role in society prior to the study abroad, including the need for cultural awareness in implementing engineering solutions. In discussing their on-site experience in implementing the bridge project in the village, students noted that while they were able to incorporate community needs into the project, they noted the need for multidisciplinary involvement and further training and preparation to adequately address the issues in an international project.

Finally, students' responses to pre- and post-questionnaire items on attitudes toward engineering and engineering learning outcomes suggest that students had a positive impression of engineering which was not notably changed by the study abroad experience. A similar pattern was noted for engineering outcomes. However, student comments related to the postquestionnaire items suggested that the activities at the host institution and the on-site service project definitely contributed to the enhancement of engineering learning outcomes. 
Future directions for our project include a more detailed and nuanced analysis of the focus group and written reflections to understand how international service learning experiences can enhance student learning and social awareness.

\section{References}

ABET. (2012). Criteria for accrediting engineering programs. Baltimore, MD: ABET.

American Society of Civil Engineers (ASCE). (2007). The vision for civil engineering in 2025:

Based on the summit on the future of civil engineering - 2025. Reston, VA: ASCE.

Retrieved from the ASCE web site, http://content.asce.org/files/pdf/TheVisionforCivil

Engineeringin2025_ASCE.pdf

American Society of Civil Engineers (ASCE). (2008). Civil engineering body of knowledge for the $21^{\text {st }}$ century: Preparing the civil engineer for the future. Reston, VA: ASCE. Retrieved from the ASCE web site, http://sections.asce.org/indiana/bok_full_rep.pdf

Duderstadt, J. J. (2008). Engineering for a changing world: A roadmap to the future of engineering practice, research, and education. Ann Arbor, MI: The Millenium Project, University of Michigan.

National Academy of Engineering (NAE). (2005). Educating the engineer of 2020: Adapting engineering education to the new century. Washington, DC: NAE.

Rugarcia, A., Felder, R. M., Woods, D. R., \& Stice, J. E. (2000). The future of engineering education: A vision for a new century. Chemical Engineering Education, 34(1), 16-25. 